Article

\title{
Body mass index, physical activity, and physical fitness of adolescence
}

\author{
Ratna Candra Dewi, Nanda Rimawati, Purbodjati \\ Faculty of Sport Science, Universitas Negeri Surabaya, Surabaya, Indonesia
}

\begin{abstract}
Background: Adolescents experience growth and significant changes in body composition which influence physical activity and response to sport or exercise. The level of physical fitness in adolescent girls is usually lower than that of boys, due to differences in body composition and levels of physical activity. The aim of this study was to examine the relationship between fat mass percentage, body composition, physical activity, and physical fitness.

Design and Methods: This study used an analytical observational, and cross-sectional design with total samples consisting of 70 male and female students aged 14-15 years. They were selected through simple random sampling, and the data collected were anthropometric measurements, body composition, physical activity and physical fitness. In addition, the Pearson correlation test was used for data analysis.

Results: The results showed that $68.57 \%$ of participants had a normal body mass index, $74.3 \%$ had moderate physical activity, and $44.28 \%$ had fat mass percentage including an obesity category and, $54.29 \%$ had low physical fitness. Furthermore, the Pearson test showed a significant relationship between physical activity, body mass index and fat mass percentage with physical fitness.

Conclusions: An increased fat mass percentage is associated with decreased levels of physical fitness. Furthermore, a good determinant of low physical fitness in obese conditions is the percentage of fat mass rather than BMI.
\end{abstract}

\section{Introduction}

Adolescence is the period between 10-19 years of age in the human life cycle. This is the period of growth and development of the body when habits are formed related to health. ${ }^{1}$ These habits include lifestyles that affect adolescent and adult health. ${ }^{2}$ Furthermore, adolescents need an average of 60 minutes each day of moderate to vigorous physical activity (MVPA). These activities can be in the form of active walking, non-school physical activities, playing, sports, and physical education. Worldwide, about $80 \%$ of teenagers are not active enough. ${ }^{3}$ Research in several European countries shows that only $26 \%$ of boys and $9 \%$ of girls are physically active, and performed MVPA $\geq 60 \mathrm{~min} / \mathrm{day}^{4}$ According to the Global Matrix 3.0 report, ${ }^{5}$ physical activity lev- els in children and adolescents are mostly low at 49 country. Furthermore, Mazur stated that only $17.2 \%$ of 11 to 15 -old years of age in Poland met the requirements of 1 hour of MVPA every day. Physical activity has a positive role on psychological and physical health. ${ }^{6}$ Júdice et al. stated that adolescents which perform moderate or vigorous physical activity, and use their free time to do an activity, significantly improve health-related fitness. ${ }^{7}$ Health in youth can be predicted from physical fitness.

Regular physical activity is an important part of a healthy lifestyle. It is associated with reduced risks of heart disease, obesity, and cancer. ${ }^{8}$ It is also important for psychological well-being with lower stress levels and better cognitive function. Recent studies show that nearly half of the US student population does not participate in moderate or vigorous physical activity. ${ }^{9}$ Therefore, this research aimed to examine the relationship between fat mass percentage, body composition, physical activity, and physical fitness.

\section{Design and Methods}

This is an analytical, observational, and cross-sectional research design. The samples totaled 70 male and female students at a junior high school in Surabaya, East Java, Indonesia which were selected by simple random sampling technique. Anthropometric measurements, including height, were performed using a microtoise. Body weight, fat mass percentage and body mass index (BMI) were measured by bioimpedance using a Tanita device (Tanita Corporation, Japan). Furthermore, the consumption intake was carried out using a $2 \times 24$ hour recall method and analyzed via a nutrisurvey. The data on physical activity was obtained via the IPAQ (International Physical Activity Questionnaire) method, while physical fitness was calculated by measuring $\mathrm{VO}_{2}$ max. The $\mathrm{VO}_{2}$ max measurements involved the application of the Multistage Fitness Test (MFT) method, which has 23 levels, each lasting approximately $1 \mathrm{~min}$. In practice, individuals go through several levels, and the speed between the beeps will decrease to give less time for the individual to complete each level, and then increase in intensity. A single sound indicates the end of each shuttle, while three simultaneous beeps signify the beginning of the next level. Data analysis used SPSS ver. 22. Descriptive analysis was calculated to determine the percentage of consumption intake, fat mass percentage, body mass index, physical activity, and physical fitness. Furthermore, the Pearson

Significance for public health

Physical fitness plays a role in maintaining physical and mental health. It is associated with fat mass percentage, body mass index, and physical activity. Low physical activity supported by a high percentage of fat mass and a high body mass index reduces physical fitness, which causes a decrease in work productivity while increasing the risk of cardiovascular disease. This study describes the relationship between energy intake, body mass index, percentage fat mass, physical activity, and physical fitness in schoolchildren aged 13-14 years. 
Correlation Test was used to analyze the relationships between variables. Before the data collection procedure, all participants were provided with information about the study and the right to withdraw at any time. A written, informed consent was submitted by participants to indicate their agreement to participate in the study.

\section{Results and Discussions}

Table 1 describes the characteristics of participants in this study and Table 2 shows a significant relationship $(<0.05)$ between fat mass percentage, body mass index, and physical activity with physical fitness. The coefficient of physical activity is positive, which means that a greater coefficient value results in increased physical fitness. Alternatively, the coefficient of body mass index and fat mass percentage is negative, which means that a greater coefficient value will reduce physical fitness.

The aim of this research was to examine the relationship between energy intake, body mass index, percentage fat mass, physical activity, and physical fitness in schoolchildren aged 13-14 years. Physical fitness is defined as "a set of attributes that people possess or attain concerning their ability to perform physical activity". It includes physiological, health-related, and skills-related fitness. Optimal energy requirements are very important for physical fitness, and its determinant is primarily physical activity, ${ }^{10}$ which includes all forms of muscular and physical exercise. Specifically, physical activity involves planned and structured body movements designed to improve physical fitness.

Adequate energy requirements are the proper amounts of dietary energy required to balance total energy expenditure (TEE) and maintain body weight. TEE reflects the sum of the resting metabolic rate $(60-75 \%)$, energy used for food-induced thermogenesis $(10 \%)$ and energy expended through physical activity (15$30 \%$ ). The energy utilized during physical activity is the most variable component of TEE. It is dependent on the subject's activity, lifestyle, type of physical exercise, gender, hormonal balance and previous nutritional status. ${ }^{11,12}$ Another study found that overweight obese adolescents used more energy expenditure and energy intake compared to other underweight or normal weight groups. ${ }^{13}$ In addition to this, certain physical activities, such as playing computer may also increase energy expenditure in adolescents. ${ }^{14}$

Overall, the results showed that the higher the body mass index, the lower the fitness level. Conversely, when physical activity is higher, physical fitness is better. Inadequate physical activity is not only associated with an increased fat mass percentage but also causes a decrease in relative muscle mass. The more muscle mass involved during exercise, the greater the contribution of muscle pump to venous return. Therefore, an increase in muscle mass helps to improve cardiac output. In this study, a negative correlation $(r=-0.615)$ was observed between fat mass percentage and physical fitness. This is a strong correlation which signifies that an increase in fat mass percentage may be responsible for a decrease in physical fitness. The observation of a higher correlation coefficient of body fat percentage and body fitness compared to BMI and fitness showed that obesity in terms of fat mass percentage was a better parameter for predicting low cardiorespiratory functional status or fitness in young adults than BMI. Therefore, during an exercise program, when possible, the measurement of percentage body fat is more significant than the BMI parameter. Increased physical activity or regular exercise can help to decrease the fat mass percentage which aids relative increases in non-fatty masses, thereby improving fitness. Additionally, health educators could motivate adolescents to maintain their physical activities in order to support and gain the benefits of normal weight. ${ }^{15-18}$ Therefore, the suggestion to reduce fat mass percentage with the help of increased physical activity or exercise would reduce health risks in young adults. ${ }^{19,20}$

In adolescents aged 12-18 years, there was a non-linear relationship observed between BMI and the results of physical fitness tests or motor performed. Respondents with an obese or obese nutritional status and other participants with skinny nutritional status had poorer fitness test scores compared to participants with normal nutritional status. ${ }^{21}$ Furthermore, in the adolescents aged 12-15 years, the best results of physical fitness measurements were held by respondents with a normal BMI level, while lower results were observed in respondents with BMI in the skinny range, and the lowest observed in individuals in the obese category. This may occur due to overweight, especially the mass of body fat that

Table 1. Characteristics of participants.

\begin{tabular}{|c|c|c|}
\hline Characteristics & n & $\%$ \\
\hline $\begin{array}{l}\text { Sex } \\
\text { Boys } \\
\text { Girls }\end{array}$ & $\begin{array}{l}35 \\
35\end{array}$ & $\begin{array}{l}50.0 \\
50.0\end{array}$ \\
\hline $\begin{array}{l}\text { Energy intake } \\
\quad<2000 \mathrm{kcal} \\
\quad 2000-2499 \mathrm{kcal} \\
2500-2999 \mathrm{kcal} \\
3000-3499 \mathrm{kcal}\end{array}$ & $\begin{array}{c}44 \\
13 \\
8 \\
5\end{array}$ & $\begin{array}{c}63 \\
19 \\
11 \\
7\end{array}$ \\
\hline Minimum & 1000 & \\
\hline Maximum & 3360 & \\
\hline Mean & 1827,8 & \\
\hline SD & 592,9 & \\
\hline $\begin{array}{l}\text { Physical activity } \\
\text { Low (<600 MET-min a day) } \\
\text { Moderate }(600-<1500 \text { MET-min a day) } \\
\text { High }(1500-<3000 \text { MET-min a day) }\end{array}$ & $\begin{array}{c}13 \\
52 \\
5\end{array}$ & $\begin{array}{c}18.5 \\
74.3 \\
7.2\end{array}$ \\
\hline $\begin{array}{l}\text { Body mass index } \\
\text { Underweight }(\mathrm{BMI} \leq 18.4) \\
\text { Normal }(\mathrm{BMI} 18.5-25) \\
\text { Overweight }(\mathrm{BMI} \geq 25.1)\end{array}$ & $\begin{array}{c}15 \\
48 \\
7\end{array}$ & $\begin{array}{c}21.4 \\
68.6 \\
10\end{array}$ \\
\hline $\begin{array}{l}\text { Fat mass percentage } \\
\text { Lean }(<8 \%) \\
\text { Optimal }(8-15 \%) \\
\text { Slightly overfat }(16-20 \%) \\
\text { Fat }(21-24 \%) \\
\text { Obesity }(>25 \%)\end{array}$ & $\begin{array}{c}8 \\
12 \\
9 \\
10 \\
31\end{array}$ & $\begin{array}{l}11.4 \\
17.2 \\
12.8 \\
14.3 \\
44.3\end{array}$ \\
\hline $\begin{array}{l}\text { Physical fitness } \\
\text { Very poor } \\
\text { Poor } \\
\text { Fair } \\
\text { Average } \\
\text { Good }\end{array}$ & $\begin{array}{l}38 \\
16 \\
10 \\
5 \\
1\end{array}$ & $\begin{array}{l}54.3 \\
22.8 \\
14.3 \\
7.2 \\
1.4\end{array}$ \\
\hline
\end{tabular}

MET, metabolic equivalents; BMI, body mass index.

Table 2. Relationship between variables. Pearson correlation ( $\mathrm{r}$ ) p-value

\begin{tabular}{lcc} 
Energy intake & 0.223 & 0.064 \\
Fat mass percentage & -0.615 & 0.000 \\
\hline Body mass index & -0.276 & 0.021 \\
Physical activity & 0.441 & 0.000 \\
\hline
\end{tabular}


shows inaction because it takes more energy and longer time to efficiently move the entire body mass. ${ }^{22-25}$

\section{Conclusions}

An increased fat mass percentage is associated with decreased levels of physical fitness, and an increase in fat free mass significantly increases physical fitness in healthy young adults. In addition, obesity in terms of percentage fat mass is a better determinant than BMI for low physical fitness.

Correspondence: Ratna Candra Dewi, Faculty of Sport Science, Universitas Negeri Surabaya, Kampus Lidah Wetan, Surabaya, Indonesia.

Tel. +62.317532571 - Fax: +62.317532759

E-mail: ratnadewi@unesa.ac.id

Key words: Body mass index; fat mass percentage; physical activity; physical fitness.

Acknowledgments: The authors are grateful to the Faculty of Sport Science, Universitas Negeri Surabaya for their kind support and encouragement during this study.

Contributions: All authors contributed equally to this article.

Conflict of interests: The author declares no potential conflict of interest.

Funding: This study was financially supported by the Faculty of Sport Medicine, Universitas Negeri Surabaya.

Conference presentation: Part of this study was presented at the $1^{\text {st }}$ International Nursing and Health Sciences Symposium, November $13^{\text {th }}$ to $15^{\text {th }} 2020$, Brawijaya University, Malang, Indonesia.

Received for publication: 14 January 2021.

Accepted for publication: 23 March 2021.

(Copyright: the Author(s), 2021

Licensee PAGEPress, Italy

Journal of Public Health Research 2021;10:2230

doi:10.4081/jphr.2021.2230

This work is licensed under a Creative Commons Attribution

NonCommercial 4.0 License (CC BY-NC 4.0).

\section{References}

1.Patton GC, Viner R. Pubertal transitions in health. Lancet 2007;369:1130-9.

2.Bélanger M, Sabiston CM, Barnett TA, et al. Number of years of participation in some, but not all, types of physical activity during adolescence predicts level of physical activity in adulthood: Results from a 13-year study. Int J Behav Nutr Phys Act 2015;12:1-8.

3. Guthold R, Stevens GA, Riley LM, et al. Global trends in insufficient physical activity among adolescents: a pooled analysis of 298 population-based surveys with 1.6 million participants. Lancet Child Adolesc Heal 2020;4:23-35.

4.Konstabel K, Veidebaum T, Verbestel V, et al. Objectively measured physical activity in European children: The IDEFICS study. Int J Obes 2014;38:S135-43.
5.Li J, Siegrist J. Physical activity and risk of cardiovascular disease--a meta-analysis of prospective cohort studies. Int J Environ Res Public Health 2012;9:391-407.

6.Beals KA, Manore MM. Disorders of the female athlete triad among collegiate athletes. Int J Sport Nutr Exerc Metab 2002;12:281-93.

7.Júdice PB, Silva AM, Berria J, et al. Sedentary patterns, physical activity and health-related physical fitness in youth: A cross-sectional study. Int J Behav Nutr Phys Act 2017;14:7-9.

8. Coyle YM. Lifestyle, genes, and cancer. Methods Mol Biol 2009;472:25-56.

9.Douglas KA, Collins JL, Warren C, et al. Results from the 1995 national college health risk behavior survey. J Am Coll Health Assoc 1997;46:55-67.

10. Ajrullah A, Nagar R, Nunn J, et al. The effects of high intensity interval training (HIIT) versus moderate intensity continuous exercise (MICE) on lipid profile in adults with Metabolic syndrome - a systematic review and meta-analyses. J Human Nutr Dietetics 2017;30:s35-9.

11. Genton L, Melzer K, Pichard C. Energy and macronutrient requirements for physical fitness in exercising subjects. Clin Nutr 2010;29:413-23.

12. Cheng HL, Amatoury M, Steinbeck K. Energy expenditure and intake during puberty in healthy nonobese adolescents: a systematic review. Am J Clin Nutr 2016;104:1061-74.

13. Graves L, Stratton G, Ridgers ND, et al. Energy expenditure in adolescents playing new generation computer games. $\mathrm{Br} \mathrm{J}$ Sports Med 2008;42:592-94.

14.Zalilah MS, Khor GL, Mirnalini K, et al. Dietary intake, physical activity and energy expenditure of Malaysian adolescents. Singapore Med J 2006;47:491.

15. Marandi SM, Abadi NG, Esfarjani F, et al. Effects of intensity of aerobics on body composition and blood lipid profile in obese/overweight females. Int J Prev Med 2013;4:S118-25.

16. Keating SE, Machan EA, O'Connor HT, et al. Continuous exercise but not high intensity interval training improves fat distribution in overweight adults. J Obes 2014;2014:834865.

17. Swift DL, Johannsen NM, Lavie CJ, et al. The role of exercise and physical activity in weight loss and maintenance. Prog Cardiovasc Dis 2014;56:441-7.

18. Shete AN, Bute SS, Deshmukh PR. A study of VO2 max and body fat percentage in female athletes. J Clin Diagnostic Res 2014;8:BC01-3.

19. Warburton DE, Nicol CW, Bredin SS. Health benefits of physical activity: the evidence. CMAJ 2006;174:801-9.

20. Kumar B, Robinson R, Till S. Physical activity and health in adolescence. Clin Med (Lond) 2015;15:267-72.

21. Mak K-K, Ho S-Y, Lo W-S, et al. Health-related physical fitness and weight status in Hong Kong adolescents. BMC Public Health 2010;10:1-5.

22. Faigenbaum AD, McFarland JE, Schwerdtman JA, et al. Dynamic warm-up protocols, with and without a weighted vest, and fitness performance in high school female athletes. J Athl Train 2006;41:357-63.

23. Committee on Fitness Measures and Health Outcomes in Youth, Food and Nutrition Board, Institute of Medicine, Pate R, et al. Fitness measures and health outcomes in youth. Washington: National Academies Press (US); 2012. Available from: https://www.ncbi.nlm.nih.gov/books/NBK241316/

24. Chung S. Body mass index and body composition scaling to height in children and adolescent. Ann Pediatr Endocrinol Metab 2015;2:125-9.

25. Nuttall FQ. Body mass index: Obesity, BMI, and health: A critical review. Nutr Today 2015;50:117-28. 